\title{
Extraction, Purification and Industrial Applications of Pectinase: A Review
}

\author{
Javed $\mathbf{R}^{1}$, Nawaz $\mathrm{A}^{1 *}$, Munir $\mathbf{M}^{2}$, Hanif $\mathbf{M U}^{1}$, Mukhtar $\mathbf{H}^{1}$, Ul Haq $\mathbf{I}^{1}$ and Abdullah $\mathbf{R}^{2}$ \\ ${ }^{1}$ Institute of Industrial Biotechnology (IIB), GC University Lahore, Pakistan \\ ${ }^{2}$ Department of Biotechnology, Lahore College for Women University Lahore, Pakistan \\ *Corresponding author: Nawaz A, Institute of Industrial Biotechnology (IIB), GC University Lahore, Pakistan \\ Submission: 監July 12, 2018; Published: 海 August 08, 2018
}

\begin{abstract}
Pectin is a hetero-polysaccharide molecule with 1,4-linked $\alpha$-D- galacturonic acid as principle component. Pectinase enzyme is responsible for the breakage of glyosidic bonds of galacturonic acid's residue present in pectic substances. For the production of pectinase enzyme both types of submerged and solid-state fermentation (SSF) are usually used. Mostly, the production of enzyme is found better in SSF. There are certain different techniques like filtration, dialysis, ammonium salt precipitation, gel filtration chromatography, Ion exchange chromatography and SDS-PAGE which can be applied for purification of pectinase enzyme. Pectinase plays an important role in industrial processes such as fruit juice extraction, degumming of plant fiber, waste water treatment, oil extraction, coffee and tea fermentation, paper and pulp industry.
\end{abstract}

Keywords: Biomolecule; Polysaccharide; Enzymology; Fermentation

\section{Introduction}

The use of living organisms in industrial process for development of different products becomes vital due to less energy consumption. Micro-organisms are beneficial for society as they are responsible for producing important products like enzymes, antibiotics, vaccines, cheese, bread and many others [1]. Enzymes extracted from microbes are used in industrial sector because of environmental friendly nature. Microbial enzymes replace the use of chemicals in both technical and industrial process which lowers the pollution rate. One such enzyme is pectinase to be used in different industries that can be produced from different microorganisms such as bacteria and fungi [2]. The compounds which are catalyzed by pectinolytic enzymes have a generic name known as pectic substances (Figure 1). These are acidic and have negative charge [3].

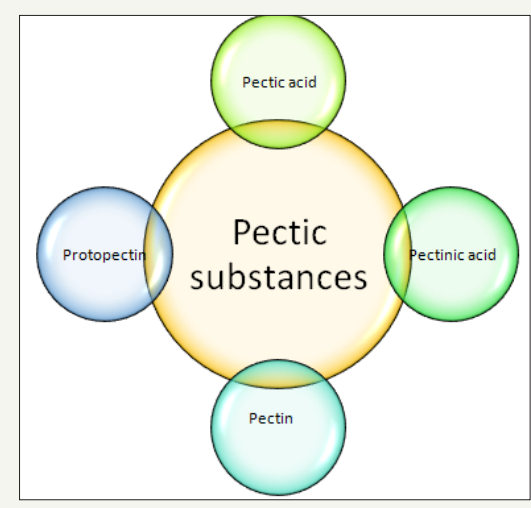

Figure 1: Classification of pectic substances [3].
There are four types of pectic substances classified by American chemical society [4]:

A. Pectic acid: It is the galacturonan's polymer having a property of solubility and the methoxyl groups are negligible. Pectate is the acidic or normal salt of pectic acid [5].

B. Protopectin: This pectic substance is insoluble in water. Intact tissues of plants contain protopectin. Due to restricted hydrolysis protopectin produces pectic acid or pectin [6]

C. Pectinic acids: The cahin of polygalacturon is pectinic acid having methylated units of galacturonate. Normal and acidic salts of pectinic acid are called pectinates [5].

D. Pectin: Pectin is generally known as polymethyl galacturonate. In pectin, galacturonate units carboxyl groups from which upto $75 \%$ are linked with methanol by estrification. By binding to cellulose in cell wall, it provides rigidity to cell wall [3].

Fruits are major pectin source and the high viscosity of fruit juices is due to mechanical crushing of fruits which are rich in pectin. To extract juice by mechical method is difficult [7]. Pectinase along with some other enzymes replaces the mechical extraction process and clarify the jucie obtained from pectin containing fruit (Table 1). Pectinase enzyme is responsible for the breakage of glycosidic bonds of galaturonic acid's residues present in pectic substances [8]. Pectinase is a complex of enzymes enzyme also known as pectic enzyme complex which includes pectozyme, pectolyase and polygalacturonase involved in pectin breakdown. Polygalacturonase 
is commercially used pectinase. The pectinolytic enzyme has been divided into three major groups that are Protopectinase, Esterase, and Depolymerase [6].

Table 1: Pectic content of different fruits.

\begin{tabular}{|c|c|c|}
\hline Sources & Pectin Content (\%) & Sources \\
\hline Orange & 29 & {$[1]$} \\
\hline Apple & $0.5-1.6$ & {$[7]$} \\
\hline Peach & $0.3-1.6$ & {$[7]$} \\
\hline Sugar beet pulp & 30 & {$[1]$} \\
\hline
\end{tabular}

Proto-pectinases act by degrading the insoluble protopectin and produce in soluble proteins. Esterases remove methoxy ester D-galaturonic acids by the deesterification of pectin while $\alpha$-(14)-glycosidic bonds present in D-galaturonic acid, is subjected to hydrolytic cleavage by deploymerases [3]. For the production of pectinolytic enzymes, both submerged and solid-state fermentation can be employed. The use of stirred tank bioreactors is preferred in the submerged process because it has the upside of controlled aeration and agitation rate which facilitates in the maximum transfer of Oxygen [9]. Conditions for culture medium are provided such that they are in accordance with the natural habitat of filamentous fungi. It gives the added benefit of maximum production because the fungi acclimatize to the culture conditions, thus escalating its efficiency. Moreover, these processes provide an uplift in the economy of the countries which are rich in deposits of biomass and agricultural waste [10].

\section{Production and Extraction of Pectinase Enzyme}

\section{Submerged fermentation}

Submerged fermentation and SSF, both can be employed to produce pectinase. The process which uses liquid broth to culture organisms is called submerged fermentation (Table 2). The prerequisites for submerged fermentation are continuous agitation, provision of large amount of water. A colossal amount of effluents is released in this process [11-15]. After production of enzyme, it is easily extracted by using Whatman filter-paper 4. Biomass stays on the filter paper and liquid as supernatant passes through it [16]. The broth is centrifuged for measuring activity of pectinase [17].

Table 2: Comparison of different media used for submerged fermentation.

\begin{tabular}{|c|c|c|c|c|}
\hline Micro-organism & Media Composition (g/L) & Spore Suspension for Inoculation (Spores/mL) & Conditions & Source \\
\hline $\begin{array}{l}\text { Penicillium } \\
\text { chrysogenum }\end{array}$ & $\begin{array}{c}\text { Citrus pectin: } 10 \\
\mathrm{~K}_{2} \mathrm{HPO}_{4}: 6 \\
\left(\mathrm{NH}_{4}\right) 2 \mathrm{SO}_{4}: 1.4 \\
\mathrm{MgSO}_{4} \cdot 7 \mathrm{H}_{2} \mathrm{O}: 0.1 \\
\mathrm{KH}_{2} \mathrm{PO}_{4}: 2\end{array}$ & $10^{6}$ & $\begin{array}{l}\text { Temp: } 30^{\circ} \mathrm{C} \\
\text { at } 150 \mathrm{rpm} \\
\text { Duration: } \\
\text { 5days }\end{array}$ & [12] \\
\hline $\begin{array}{c}\text { Streptomyces sp. } \\
\text { GHBA10 }\end{array}$ & $\begin{array}{c}\text { Pectin; } 5 \\
\text { Yeast extract: } 1 \\
\mathrm{MgSO}_{4} 7 \mathrm{H}_{2} \mathrm{O}: 1 \\
\mathrm{NaCl}^{2} 2 \\
\mathrm{KH}_{2} \mathrm{PO}_{4}: 4 \\
\mathrm{MnSO}_{4}: 0.05 \\
\mathrm{CaCl}_{2} \cdot 2 \mathrm{H}_{2} \mathrm{O}: 2 \\
\mathrm{NH}_{4} \mathrm{Cl}: 2 \\
\mathrm{FeSO}_{4} \cdot 7 \mathrm{H}_{2} \mathrm{O}: 0.05\end{array}$ & $10^{6}$ & $\begin{array}{l}\text { Temp: } 30{ }^{\circ} \mathrm{C} \\
\text { at } 150 \mathrm{rpm} \\
\text { Duration: } \\
\text { 5days }\end{array}$ & [13] \\
\hline $\begin{array}{l}\text { A. oryzae, } \\
\text { A. flavus }\end{array}$ & $\begin{array}{c}\text { Rice bran: } 10 \\
\mathrm{~K}_{2} \mathrm{HPO}_{4}: 6.0 \\
\left(\mathrm{NH}_{4}\right) 2 \mathrm{SO}_{4}: 6 \\
\mathrm{MgSO}_{4} \cdot 7 \mathrm{H}_{2} \mathrm{O}: 0.1 \\
\mathrm{KH}_{2} \mathrm{PO}_{4}: 6\end{array}$ & $10^{6}$ & $\begin{array}{l}\text { Temp: } 30{ }^{\circ} \mathrm{C} \\
\text { at } 150 \mathrm{rpm} \\
\text { Duration: } \\
48 \mathrm{hrs}\end{array}$ & {$[14]$} \\
\hline Aspergillus niger & $\begin{array}{c}\mathrm{MgSO}_{4} 7 \mathrm{H}_{2} \mathrm{O}: 0.1 \\
\mathrm{NH}_{4} \mathrm{NO}_{3}: 0.1 \\
\mathrm{NH}_{4} \mathrm{H}_{2} \mathrm{PO}_{4}: 0.1 \\
\text { Ground mango peels: } 1 \%\end{array}$ & One disc of actively growing Aspergillus niger & $\begin{array}{l}\text { Temp: room } \\
\text { temp } \\
\text { Duration: } 4 \\
\text { days }\end{array}$ & [15] \\
\hline
\end{tabular}

\section{Solid state fermentation}

The process in which growth is proceeded on a solid surface or particles, in the absence or partial presence of water is termed as solid-state fermentation $[18,19]$. For extraction of enzyme after fermentation, the particular amount of specific buffer and water added into the fermented flask and allowed to mix well by using mechanical stirring. Filtration and centrifugation was done after mixing and centrifugation was carried out for obtaining the clear extract of enzyme [20]. Different fungal strains are metabolically 
different and grow differently in different media (Table 3). Some fungal strains are not able to produce enzyme under solid state

\section{Microbial sources}

Table 3: Comparison of different media used for SSF. fermentation but become active when submerged conditions were provided [21,22].

\begin{tabular}{|c|c|c|c|c|c|}
\hline $\begin{array}{l}\text { Micro-or- } \\
\text { ganism }\end{array}$ & $\begin{array}{l}\text { Solid Sub- } \\
\text { strate }\end{array}$ & $\begin{array}{l}\text { Media Composition for } \\
100 \mathrm{~mL}\end{array}$ & $\begin{array}{c}\text { Spore Suspension for Inoculation } \\
\text { (Spore/g per Dry Matter) }\end{array}$ & $\begin{array}{l}\text { Incubation } \\
\text { Conditions }\end{array}$ & Source \\
\hline $\begin{array}{l}\text { Aspergillus } \\
\text { niger }\end{array}$ & $\begin{array}{l}\text { Sugar beet } \\
\text { pulp: } 10 \mathrm{~g}\end{array}$ & $\begin{array}{cc}\mathrm{KH}_{2} \mathrm{PO}_{4}: & 0.04 \mathrm{~g} \\
\mathrm{Na}_{2} \mathrm{HPO}_{4} 12 \mathrm{H}_{2} \mathrm{O}: & 0.02 \mathrm{~g} \\
\text { Water: } 11 \mathrm{ml}\end{array}$ & $2 \times 10^{6}$ spores & $\begin{array}{c}\text { Temp: } 30{ }^{\circ} \mathrm{C} \\
\text { Duration: } 96 \mathrm{~h}\end{array}$ & [19] \\
\hline $\begin{array}{l}\text { Penicillium } \\
\text { sp EGC5 } \\
\text { P. viridica- } \\
\text { tum RFC3 }\end{array}$ & $\begin{array}{c}\text { Wheat } \\
\text { bran } \\
\text { Sugarcane } \\
\text { bagasse } \\
(9: 1) \text { or } \\
(1: 9)\end{array}$ & $\begin{array}{c}\mathrm{NH}_{4} \mathrm{NO}_{3}: 0.1 \% \\
\mathrm{MgSO}_{4} \times 7 \mathrm{H}_{2} \mathrm{O}: 0.1 \% \\
\mathrm{NH}_{4} \mathrm{H}_{2} \mathrm{PO}_{4}: 0.1 \%\end{array}$ & $10^{7}$ spores & $\begin{array}{c}\text { Temp: } 30{ }^{\circ} \mathrm{C} \\
\text { Duration: } 15 \\
\text { days }\end{array}$ & {$[20]$} \\
\hline $\begin{array}{l}\text { Aspergillus } \\
\text { niger } \mathrm{CH}_{4} \\
\text { strain }\end{array}$ & $\begin{array}{l}\text { Sugar cane } \\
\text { bagasse: } \\
23.1 \mathrm{~g}\end{array}$ & $\begin{array}{c}\text { Sucrose: } 3.14 \mathrm{~g} \\
\text { Pectin: } 1.5 \mathrm{~g} \\
\text { Potassium phosphate: } 0.65 \mathrm{~g} \\
\text { Ammonium sulfate: } 1.26 \mathrm{~g} \\
\text { Magnesium sulfate: } 0.02 \mathrm{~g} \\
\text { Urea: } 0.3 \mathrm{~g} \\
\text { Ferrous sulfate: } 0.029 \mathrm{~g} \\
\text { Water: } 80 \%\end{array}$ & $2 \times 10^{7}$ & Temp: $35^{\circ} \mathrm{C}$ & [21] \\
\hline $\begin{array}{l}\text { Trichoder- } \\
\text { ma harzia- } \\
\quad \text { num }\end{array}$ & $\begin{array}{l}\text { Ground } \\
\text { powder } \\
\text { of peel } \\
\text { of Citrus } \\
\text { sinensis: }\end{array}$ & $\begin{array}{c}\text { Yeast extract: } 0.5 \mathrm{~g} \\
\text { Glucose: } 2.5 \mathrm{~g} \\
\text { Peptone: } 0.1 \mathrm{~g} \\
\mathrm{KH}_{2} \mathrm{PO}_{4}: 0.4 \mathrm{~g} \\
\text { Trisodium citrate: } 0.5 \mathrm{~g} \\
\mathrm{MgSO}_{4} \cdot 7 \mathrm{H}_{2} 0: 0.2 \mathrm{~g} \\
\left(\mathrm{NH}_{4}\right) 2 \mathrm{SO}_{4}: 0.4\end{array}$ & $10^{7}-10^{8}$ & Temp: $28{ }^{\circ} \mathrm{C}$ & {$[22]$} \\
\hline
\end{tabular}

Aspergillus niger, Aspergillus. awamori, Penicillium restrictum, Trichoderma viride, Mucor piriformis and Yarrowia lipolytica are the filamentous fungi employed in both submerged as well as solid state fermentation for production of various industrially important products such as citric acid, ethanol etc. [23,24]. Aspergillus niger, Aspergillus oryzae, Penicillium expansum, are the types of fungi which are considered as safe (GRAS) by United States Food and Drugs Administration (USFDA) and are put to use in food industry. Some bacteria (Bacillus licheniformis, Aeromonas cavi, Lactobacillus, etc), yeasts like Saccharomyces, Candida and Actinomycetes like Streptomycetes are also used. Amongst these, the filamentous fungi are most commonly employed [11].

\section{Importance of solid state fermentation over submerged fermentation}

Solid state fermentation is opted in place of submerged fermentation because it has more advantages [10] as the one is that it uses substrates which are considered as waste but actually contains nutrients. These substrates are important for long term use in fermentation because of their slow utilization rate [25]. Solid state fermentation gives more products after extraction as compared to submerged fermentation [22]. As in the example Penicillium citrinum produced more percentage yield of pectinase in solid as compared to submerged fermentation and is shown below (Table 4) [26]. 
Table 4: Comparison of units obtained from solid state and submerged fermentation.

\begin{tabular}{|c|c|c|c|c|}
\hline Fermentation Type & Source & SSF (units/gds) & SmF $(\mu \mathrm{mol} / \mathrm{ml} / \mathrm{min})$ & Source \\
\hline Pectin lyase & Penicillium citrinum & 2.07 & 0.052 & {$[26]$} \\
\hline Polygalacturonase & Penicillium citrinum & 34.2 & 0.067 & {$[26]$} \\
\hline
\end{tabular}

\section{Purification}

The enzyme, pectinase may have extracted from different sources by using fermentation techniques. It is necessary to purify it for further processing. The purification steps are following [17]:

\section{Filtration}

If enzyme and the spore's bodies are required to separate, then filtration is the best technique. In this filtration is done using Filter paper and centrifugation is carried out for 15 minutes at a rpm of 10,000 . The resulting enzyme extract is used for pectinase activity assay [17].

\section{Ethanol precipitation}

For ethanol precipitation, crude enzyme must be dialyzed and the resultant supernatant has been mixed with chilled ethanol. Up to 3 volumes of ethanol were used and the mixture was placed undisrupted at a temperature of $4{ }^{\circ} \mathrm{C}$ overnight [27]. Centrifugation of resultant precipitate after overnight incubation was carried out at same temperature at $9,000 \times$ g. Time for centrifugation was 30 minutes. $10 \mathrm{~mL}$ Sodium citrate buffer with a $\mathrm{pH}$ of 6.5 was used for dissolving the precipitate [28].

\section{Ammonium sulfate precipitation}

Supernatant was used as an enzyme source obtained by the centrifugation of cultural medium. The enzyme precipitated by the addition of 60 percent ammonium sulfate [27]. Incubate it for overnight at a temperature of $40{ }^{\circ} \mathrm{C}$ after that centrifugation was done for twenty minutes at a rpm of 5000. Dissolved the resultant pellet in appropriate buffer such as T.E. buffer (pH 7.0) [6].

\section{Dialysis}

Activation of dialysis membrane is mainly achieved by sodium bi carbonate, and by boiling in hot water. This membrane contains dialysis tubing and after the activation of membrane the partially purified sample was added in to it and sealed it [28]. The salt impurities from protein extract was allowed to remove by suspending the tube in water and then incubated overnight [17].

\section{Ion exchange chromatography}

This chromatography technique helps mainly in the removal of proteins either bound or unbound [27]. Sephadex G 150 is used for packing the glass column. After packing, the sample have been loaded into column. Tris $\mathrm{HCl}$ was used for protein elution in this method, having a $\mathrm{pH}$ 7.5. The volume collected after void volume were fractions of $1.5 \mathrm{ml}$ and their absorbance were taken. Those fractions having positive results for pectinase activity were saved by pooling out and concentrated them for further processing [23].

Gel filtration chromatography: The sample which was properly dialyzed, loaded in a column which is Sephadex G-250.
$0.2 \mathrm{M}$ solution of phosphate buffer having a $\mathrm{pH}$ of 7.5 was used for column equilibration. The same buffer was used for protein elution. The flow rate was $0.1 \mathrm{ml} / \mathrm{min}$ and with this rate the which were collected were ten. Factions having pectinase activity were separated out for further analysis [7].

\section{SDS- Page}

SDS PAGE was used for purity checking. Molecular weight was determined by running the marker and purified enzyme. Coomassie brilliant blue is used for staining the gel band for clear visualized [29].

Different purification techniques having different conditions become suitable for one but not for other proteins [30]. The slight change in $\mathrm{pH}$ above or below the optimum value change the activity of enzyme which could be a reason for variation in percentage yield of same proteins using different purification strategies.

\section{Application}

One of the enzymes, that are the reason of unprecedented success of the textile and fruit industries, is pectinase [1]. Pectinases have a variety of applications in the industrial sector. This particular enzyme is used in the extraction of fruit juices such as apples, grape wine, strawberries, grapes, raspberries etc [31]. Pectin have a vital role in the turbidity and viscosity of fruits. For the purpose of clarifying fruit juices, a mixture of amylases and pectinases is used. The time of filtration is decreased upto 50\% [32]. Pectinases are applied for the treatment of waste water coming from different industries [33]. Textile processing and bioscouring of cotton also finds a role of pectinase in their process. Pectinases combined with lipases, amylases, cellulases and hemicelluloses, is being used in place of caustic soda which is toxic in nature [34]. Pectinase is also used in paper making. It has the ability to depolymerize pectin. Pectin has a higher cationic demand which is lowered by the implementation of pectinase and the filtrate from peroxidase [35]. Besides all these, fermentation of tea and coffee [36], oil extraction and [37], and animal feed production also requires pectinase [34].

\section{Conclusion}

Pectinases are of humongous importance as they can be employed in a variety of industrial processes which ultimately leads to an escalation in the quality and yield of the product. A great deal of work done on pectinases involves its screening, isolation, production, purification, characterization and application in the arena of fruit juice production and clarification. Apart from fruit industry, other industries also enjoy the perks of pectinases according to some reports. In the coming times, protein engineering and the technique of site directed mutagenesis should be applied to search for the molecular aspects of pectinases which can increase its robustness regarding the $\mathrm{pH}$ and temperature kinetics. The main 
focus of research on pectinase should be its regulatory mechanism of secretion at a molecular level in the future. This will also aid in the understanding of how different pectinolytic enzymes act on pectin substances.

\section{References}

1. Pasha KM, Anuradha P, Subbarao D (2013) Applications of pectinases in industrial sector biotechnological applications of microbial pectinases. Int J Pure Appl Sci Technol 16(1): 89-95.

2. Priya V, Sashi V (2014) Pectinase enzyme producing microorganisms. IJSRP 4(3): 1-4

3. Reddy PL, Sreeramulu A (2012) Isolation, identification and screening of pectinilytic fungi from different soil samples of Chittoor district. Int J Life Sc Bt \& Pharm Res 1(3): 186-193.

4. Alkorta I, Garbisu C, Llama MJ, Serra JL (1998) Industrial applications of pectic enzymes: A review. Proc Biochem 33(1): 21-28.

5. Kilara A (1982) Enzymes and their uses in the processed apple industry: A Review. Process Biochem 23: 35-41.

6. Tripathi GD, Javed Z, Singh AK (2014) Pectinase production and purification from Bacillus subtilis isolated from soil. Adv Appl Sci Res 5(1): 103-105.

7. Tapre AR, Jain RK (2014) Pectinases: Enzymes for fruit processing industry. Int Food Res J 21(2): 447-453.

8. De Gregorio A, Mandalari G, Arena N, Nucita F, Tripodo MM, et al. (2002) SCP and crude pectinase production by slurry-state fermentation of lemon pulps. Bioresource Technology 83(2): 89-94.

9. Zeni J, Ambrozini É, Pili J, Cence K, Toniazzo BG, et al. (2015) Production and characterization of Penicillium brasilianum pectinases with regard to industrial application. Biocatalysis Biotransformation 33(5-6): 270278.

10. Castilho LR, Medronho RA, Alves TLM (2000) Production and extraction of pectinases obtained by solid state fermentation of agroindustrial residues with Aspergillus niger. Bioresource Technology 71(1): 45-50.

11. Geetha M, Mahalakshmi S, Reetha D (2012) Screening of pectinase producing bacteria and fungi for its pectinolytic activity using fruit wastes. Int J Biochem Biotech Sci 1: 30-42.

12. Banu RA, Devi KM, Gnanaprabhal GR, Pradeep VB, Palaniswamy M, et al. (2010) Production and characterization of pectinase enzyme from Penicillium chrysogenum. Indian J Sci Technol 3(4): 377-381.

13. Arijit D, Sourav B, Naimisha R, Rajan SS (2013) Improved production and purification of pectinase from Streptomyces spp. GHBA10 isolated from Valapattanam mangrove habitat, Kerala, India. Int J Biol Sci 2(3): 16-22.

14. Thangaratham T, Manimegalai G (2014) Optimization and production of pectinase using agro waste by solid state and submerged fermentation. Int J Curr Microbiol App Sci 3(9): 357-365.

15. Ezike TC, Oscar S, Chukwunonso AN, Chilaka FC (2001) Production of pectinases from Aspergillus niger using submerged fermentation with orange peels as carbon source. SYLWAN 158(8): 434-440.

16. Díaz G, Soriano SJ, Augur C, Viniegra GG (2001) Exopectinases produced by Aspergillus niger in solid-state and submerged fermentation: a comparative study. J Ind Microbiol Biotechnol 26(5): 271-275.

17. Beulah D, Sunitha EM, Srilakshmi T (2015) Production, purification and assay of pectinase enzyme from Aspergillus niger. HELIX 2: 673-677.

18. Ghosh JS (2016) Solid state fermentation and food processing: A Short Review. Int J Food Sci Nutr 6(1): 1-7.
19. Bai ZH, Zhang HX, Qi HY, Peng XW, Li BJ (2004) Pectinase production by Aspergillus niger using wastewater in solid state fermentation for eliciting plant disease resistance. Bioresour Technol 95(1): 49-52.

20. Martin N, De Souza SR, Da Silva R, Gomes E (2004) Pectinase production by fungal strains in solid-state fermentation using agro-industrial bioproduct. Braz Arch Biol Technol 47(5): 813-819.

21. Acuña-Argüelles ME, Gutiérrez-Rojas M, Viniegra-González G, FavelaTorres E (1995) Production and properties of three pectinolytic activities produced by Aspergillus niger in submerged and solid-state fermentation. Appl Microbiol Biotechno 43(5): 808-814.

22. Nabi NG, Asgher M, Shah AH, Sheikh MA, Asad MJ (2003) Production of pectinase by trichoderma harzianum in solid state fermentation of citrus peels. Pak J Agr Sci 40(3-4): 193-201.

23. Kashyap DR, Chandra S, Kaul A, Tewari R (2000) Production, purification and characterization of pectinase from a Bacillus sp. DT7. World J Microbiol Biotechnol 16(3): 277-282.

24. Bhardwaj V, Garg N (2014) Production, purification of pectinase from Bacillus sp MBRL576 isolate and its application in extraction of juice. International Journal of Science and Research 3(6): 648-652.

25. Subramaniyam R, Vimala R (2012) Solid state and submerged fermentation for the production of bioactive substances: A comparative study. Int J Sci Nat 3(3): 480-486.

26. Sandhya R, Kurup G (2013) Screening and isolation of pectinase from fruit and vegetable wastes and the use of orange waste as a substrate for pectinase production. Int Res J Biological Sci 2(9): 34-39.

27. Khairnar Y, Krishna A, Gupta BN, Trivedi S, Patil P, et al. (2009) Study of pectinase production in submerged fermentation using different strains of Aspergillus niger. Int J Microbiol Res 1(2): 13-17

28. Banu AR, Devi MK, Gnanaprabhal GR, Pradeep BV, Palaniswamy M (2010) Production and characterization of pectinase enzyme from Penicillium chrysogenum. Indian J Sci Technol 3(4): 377-381.

29. Patil NP, Chaudhari BL (2010) Production and purification of pectinase by soil isolate Penicillium sp and search for better agro-residue for its SSF. IJRST 2(7): 36-42.

30. Polizeli MDL, Jorge JA, Terenzi HF (1991) Pectinase production by Neurospora crassa: purification and biochemical characterization of extracellular polygalacturonase activity. J Gen Microbiol 137(8): 18151823

31. Gailing MF, Guibert A, Combes D (2000) Fractional factorial designs applied to enzymatic sugar beet pulps pressing improvement. Bioprocess Eng 22(1): 69-74.

32. Blanco P, Sieiro C, Villa TG (1999) Production of pectic enzymes in yeasts. FEMS Microbiol Lett 175(1): 1-9.

33. Tanabe H, Yoshihara K, Tamura K, Kobayashi Y, Akamatsu I, et al. (1987) Pretreatment of pectic wastewater from orange canning process by an alkalophilic Bacillus sp. J Fermentation Technol 65(2): 243-246.

34. Hoondal GS, Tiwari RP, Tiwari R, Dahiya N, Beg QK (2000) Microbial alkaline pectinases and their applications: A review. Appl Microbiol Biotechnol 59(4-5): 409-418.

35. Reid I, Richard M, (2004) Purified pectinase lowers cationic demand in peroxide-bleached mechanical pulp. Enzyme Microbial Technol 34(5): 499-504.

36. Carr JG (1985) Tea, coffee and cocoa. In: Wood BJB (Ed.), Microbiology of fermented foods. Elsevier Science Ltd, London.

37. Peru, Scott D, Grayson M, Ekarth D, Othmer K (1978) Encyclopedia of chemical technology. Wiley, New York, USA. 
(c) (i) Creative Commons Attribution 4.0

For possible submissions Click Here Submit Article

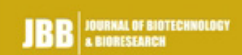 \\ Journal of Biotechnology \& Bioresearch}

\section{Benefits of Publishing with us}

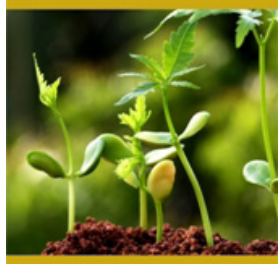

- High-level peer review and editorial services

- Freely accessible online immediately upon publication

- Authors retain the copyright to their work

- Licensing it under a Creative Commons license

- Visibility through different online platforms 